\title{
Heat rises over UCSD 'misconduct' charge
}

[SAN DIEGO] In an unusual conflict between academic officials and federal authorities, the US Department of Justice has taken over a federal lawsuit against a researcher at the University of California at San Diego (UCSD) concerning allegedly fraudulent grant applications at the same time as an academic panel at the university has suggested that the scientist should be cleared of misconduct charges.

The case stems from three-year-old allegations that Maurizio Zanetti, a former Italian physician turned immunologist, fabricated research results and violated university policies covering the use of animals in research, human experiments and biosafety standards.

The allegations were made by Paolo del Guercio, another Italian former physician who held a junior position in Zanetti's laboratory, which specialized in AIDS research. Del Guercio lost his university post after making the allegations. Zanetti denies any scientific misconduct.

Zanetti, a tenured professor, was a close colleague of the late Jonas Salk, and carried out research with the Immune Response Corporation of Carlsbad, California, which
Salk set up to try to devise a therapeutic vaccine for AIDS.

Del Guercio claims in a 'whistleblower lawsuit' filed in 1995 that Zanetti made false claims to win between $\$ 1.8$ million and $\$ 4.8$ million in grants from the National Institutes of Health. Del Guercio previously carried out research for the French national medical research agency, INSERM, in Paris, as well as for the Wellcome Foundation in Great Britain.

In 1995, an ad hoc committee of UCSD scientists, acting in response to Del Guercio's complaints, found evidence that Zanetti had fabricated data in at least two published articles. The committee suggested that Zanetti might have suppressed results of an HIV experiment so that he could obtain an NIH grant.

But two months ago, a further faculty panel set up to consider whether Zanetti should be punished decided that he had not fabricated experiments or suppressed results. This second panel did, however, conclude that Zanetti had violated the university's guidelines on experiments, and recommended that he be given a strongly worded letter of reprimand.

\section{Rifts found as Antarctic ice breaks apart}

\section{IMAGE \\ UNAVAILABLE FOR COPYRIGHT REASONS}

[LONDON] Researchers from Greenpeace, the environmentalist group, last week came across significant rifts in the southern part of the Larsen ice shelf in the Antarctic peninsula - an area known as Larsen $B$ (see above). Scientists from the British Antarctic Survey predicted last year that Larsen $B$ was beginning to rift and that eventually the neighbouring sector, Larsen C, "may well behave in a similar way" (see Nature 378, 328; 1996).

The researchers found that five Antarctic ice shelves out of nine they had studied have disintegrated in the past 50 years.
Meteorological records over the same period show that the disintegration coincided with a $2.5^{\circ} \mathrm{C}$ rise in atmospheric temperatures.

Accelerated disintegration is a common feature of retreating ice shelves in the Antarctic. The final stage of disintegration of Larsen A, the 4,200 square-kilometre northern part of the Larsen ice shelf, was marked by sudden collapse in January 1995. Some 1,300 square kilometres of ice were lost in 50 days when the ice shelf broke into thousands of small icebergs, producing a plume $200 \mathrm{~km}$ into the Weddell Sea (see Nature 374, 108; 1995).
The panel's recommendations were sent to Robert C. Dynes, the university's vicechancellor, to decide on what action should be taken. A spokeswoman for the university says that Dynes will make "an informed" decision with the benefit of "substantial input" from the panel.

Meanwhile, however, a further dimension has been added by the contents of Del Guercio's lawsuit, which was unsealed in the US District Court in San Diego. This names Zanetti (as a principal investigator), the university and a junior researcher in the laboratory, Rosario Billetta, as having made false statements to the NIH to secure grants.

Most of the allegations in the lawsuit repeat those made to the university. The grants were for research on AIDS, a malaria vaccine and a vaccine for experimental allergic encephalitis. Billetta, another Italian researcher who recently left UCSD, has denied any impropriety.

Last month, the US Attorney's Office in San Diego revealed that it was intervening in the lawsuit, using its authority in such cases to take over the prosecution, and suggesting that the government may believe that some of the allegations are true. If the court decides that NIH grants have been improperly obtained, federal officials will seek to recover them from the university - with Del Guercio sharing in the recovered funds.

Neither the federal authorities nor UCSD officials are prepared to discuss the issue. But, in a highly unusual move, Zanetti has released all documents and transcripts of the two-week hearing before the second university panel.

These reveal Zanetti's attorney, Milton J. Silverman, who specializes in high-profile criminal defence work, conducting a harsh attack on the characters of his accuser and UCSD officials. Melvin W. Beal, an attorney for the university, said during the panel's hearing that Zanetti's defence "indicates an attitude of monumental arrogance and disdain for the principles that underlie the academic enterprise".

Beal also said that "whether dealing with the canons of intellectual honesty, the safety requirements relating to biological research, human subjects or animal use, Dr Zanetti shows himself to be either utterly without recognition. of the importance of these principles or voluntarily unwilling to adhere to them".

But Silverman responded that there was "not a fraudulent bone" in Zanetti's body, describing him as "a good scientist and a decent man". Zanetti "is not perfect, he has made mistakes", said Silverman, but he "is completely innocent" of the scientific misconduct charges.
Rex Dalton 